\title{
Una música que construye. Elementos musicales claves para la generación de atmósferas emotivas en escenas de tres películas de Studio Ghibli*
}

\author{
Pamela Antillanca \\ U. de Valparaíso \\ pame.002@gmail.com
}

\begin{abstract}
Resumen
En el presente trabajo se abordará la relación sonido/imagen, poniendo especial atención a la música y a los elementos que la conforman. Se pretende obtener una visión tanto general como particular de las bandas sonoras, y para ello se analizarán tres obras musicales pertenecientes a tres películas de Studio Ghibli. Los temas son "Una ciudad con vistas al mar" de Kiki, entregas a domicilio, "Un día de verano," de El viaje de Chihiro, y "El tiovivo de la vida", de El increíble castillo vagabundo. Estas obras fueron compuestas por Joe Hisaishi y los tres films fueron dirigidos por Hayao Miyazaki.
\end{abstract}

Palabras clave

Banda sonora, análisis musical, atmósfera emotiva, Joe Hisaishi, Studio Ghibli

\section{Music that Builds. Key Musical Elements for the Generation of Emotional Atmospheres in Three Films by Studio Ghibli}

\begin{abstract}
In this article the relationship between sound and image will be addressed, paying special attention to music and the elements that build it. To discuss both a general and particular view of the soundtracks, we will analyze three musical works from three films by Studio Ghibli. The songs are "A Town with an Ocean View" from Kiki's Delivery Service, "One Summer's Day" from Spirited Away, and "Merry-Go-Round of Life" from Howl's Moving Castle. These works were composed by Joe Hisaishi and all three films were directed by Hayao Miyazaki.
\end{abstract}

Keywords

Soundtrack, musical analysis, emotional atmosphere, Joe Hisaishi, Studio Ghibli.

* Recibido: 31 de agosto de 2016 / Aceptado: 14 de noviembre de 2016.

Este artículo, basado en la tesis del mismo nombre, ha sido escrito en el marco del Fondecyt de Iniciación no 11150655 Estética del sonido en el cine de Raúl Ruiz, Investigador Responsable: Gustavo Celedón.

Todas las traducciones son de la autora. 


\title{
Música que constrói. Elementos musicais chave para a geração de atmosferas emocionais em três filmes por Studio Ghibli
}

\begin{abstract}
Abstrato
Neste artigo será abordada a relação entre som e imagem, prestando especial atenção à música e aos elementos que a compõem. Para discutir uma visão geral e particular das trilhas sonoras, vamos analisar três obras musicais de três filmes de Studio Ghibli. As músicas são "Uma cidade com vista para o oceano", de O serviço de entrega da Kiki, "Um dia de verão", de A Viagem de Chihiro, e "Carrossel da vida", de O Castelo animado. Estas obras foram compostas por Joe Hisaishi e todos os três filmes foram dirigidos por Hayao Miyazaki.
\end{abstract}

Palavras-chave

Soundtrack, análise musical, atmosfera emocional, Joe Hisaishi, Studio Ghibli. 


\section{Metodología de una dupla}

Joe Hisaishi y Hayao Miyazaki forman una pareja de compositor y director, respectivamente, y su alianza ha dado frutos importantes en el campo de la animación. La confluencia de sus estilos en diversas películas de la productora Studio Ghibli ha significado que sus nombres se asocien cada vez que se menciona a uno, aunque ambos tienen largas trayectorias en el ámbito audiovisual de manera independiente (Koizumi, 2009: 60). Hisaishi ha trabajado con Takeshi Kitano, otro director de cine japonés, y también se desempeña como director de orquesta, mientras que Miyazaki ha participado como animador en series de televisión de Toei Animation, A Pro, Nippon Animation y Tokyo Movie Shinsha, además de dibujar mangas (Bellano, 2010: 46, 7-8).

Hayao Miyazaki durante muchos años dirigió y produjo películas de animación. Participaba activamente en la creación de los personajes y escenarios, daba vida a mundos fantásticos con criaturas extrañas, expresaba a través de los dibujos sus experiencias y su punto de vista ante la existencia misma (Bellano, 2010: 6-7). Sus ideales lo llevaron a cofundar, en 1985, la productora Studio Ghibli (Koizumi, 2009: $60)$.

En 1982, a la edad de 32 años, Joe Hisaishi ya había lanzado su segundo álbum solista y colaborado con Masaru Satô y distintos directores de series de televisión (Bellano, 2010: 9-10; Koizumi, 2009: 61). Su carrera estuvo ligada al ámbito audiovisual tempranamente, aunque la mayoría de las veces sus composiciones estaban destinadas a ser música de fondo, lo que le impedía forjar un lenguaje musical propio. En 1984, en el contexto de la preproducción Nausicaä del Valle del Viento (Kaze no Tani no Naushika), Miyazaki recibió la recomendación de solicitar a Joe Hisaishi para que trabajase en la banda sonora de este film. En aquel entonces, Hisaishi tomó la composición musical como un reto y se dedicó a experimentar. Él mismo afirma: "hice todo lo posible por encontrar el camino más desafiante. Eso quiere decir que realmente no me importaba ver si la música concordaba con la imagen, o si la música reflejaba lo que me pareció ser el contenido psicológico de la escena". Con el pasar del tiempo, mientras trabajaba con Miyazaki, se produjo un cambio en esta actitud (cit. Bellano, 2010: 10).

La metodología de Hisaishi y Miyazaki tiene como base un modelo económico japonés que consiste en lanzar un álbum de imagen durante la preproducción del film, es decir, un CD que contiene pistas preliminares de la obra audiovisual finalizada (Koizumi, 2009: 62). Al respecto, Marco Bellano explica que los "compositores de películas, programas de televisión o videojuegos son usualmente solicitados para escribir durante la etapa de preproducción, usando storyboards o el concepto ar- 
tístico como una fuente de inspiración". Esta manera de trabajar tiene como objetivo lanzar un álbum CD que anticipe por varios meses el debut de la producción (Bellano, 2012: 2).

El procedimiento descrito le ha servido a Hisaishi y a Miyazaki para generar una metodología de retroalimentación, en la que las imágenes sugieren una inspiración para la música, mientras que ésta, a su vez, les otorga un valor añadido a las imágenes. El compositor describe el método así:

Es siempre el mismo proceso para cada film. La producción tarda de dos a tres años y es muy larga, porque [Miyazaki] es muy quisquilloso y exigente. Antes de entregarme el verdadero guion, me da un tipo de storyboard bastante simple, me presenta los personajes y me habla un poco de la historia. Entonces, él empieza a trabajar, mientras avanzo por mi cuenta. Él también me da diez palabras, sobre las cuales construyo mi trabajo. En el primer año, empiezo a componer la música y después de un año es posible hacer un CD: Es el primer CD de la película, el álbum de imagen, que es lanzado antes de la plena realización del trabajo. Este álbum de imagen tiene dos propósitos: Permite que me dé cuenta de cómo será la música luego, pero también le permite a Miyazaki, quien continúa dibujando, trabajar mientras escucha la música (cit. Bellano, 2010: 11).

El trabajo que requiere organizar esta estrategia por parte de la dupla japonesa, demuestra que, desde el inicio, ya hay una intención de comunicar con ambos elementos de la obra audiovisual. La preproducción, además de seguir el modelo económico de álbum de imagen, se centra en la entrega de un mensaje al espectador, haciendo que la cadena formada por música/imagen sea un lenguaje distinto al que cada una es por separado.

Nuestra investigación se basó en identificar el o los elementos musicales claves de la banda sonora musical que participan en la construcción de la atmósfera emotiva de las escenas, por lo que recurrimos a la fuente original con el objetivo de obtener datos para interpretar. Los datos recolectados se agruparon en tablas, y corresponden al minutaje de inicio y de fin de las intervenciones de las pistas musicales. La columna "Título" indica una denominación (dada por quien escribe) que engloba la situación en la que va la historia. La columna "Soundtrack" indica el nombre de la pista en el CD. La celda está vacía si no hay correspondencia con lo que se escucha. "Duración" y "OST" muestran la duración de la pista en la película y en el $C D$, respectivamente. Agregamos también espectrogramas de la banda sonora de cada película, una representación gráfica del espectro acústico en los que se puede apreciar la variación de frecuencia y de dinámica de la señal sonora conforme el tiempo transcurre.

Al proceso de recolección de datos y anotación en tablas lo llamamos découpage musical. Este desglose sirve como referente en cuanto a los nombres de las pistas y a su duración e intervención en los films. Posibilita una visión general del empleo de los temas musicales, pero también entrega datos particulares (como lo es afirmar 
que en Kiki, entregas a domicilio, se oye música durante el 39,8\% de la película). Las celdas se colorearon con el objetivo de reconocer el/los motivo/s central/es y las similitudes entre las pistas a lo largo de toda la película en cuestión. Se siguió este proceso en la columna "Título" y una segunda revisión se aplicó a "Soundtrack".

Fabricando nuestro découpage musical, pudimos observar algunas importantes diferencias entre las bandas sonoras de las películas. Una de ellas es la que se da entre las dos primeras respecto de la última, El increíble castillo vagabundo, del año 2004. Esta película, basada en la novela El castillo ambulante (Howl's moving castle), de Diana Wynne Jones, es la única de las tres que presenta el concepto de leit motiv como tal, pues es la única en la que se identifica claramente un motivo musical central que se repite, con algunas variaciones rítmicas e instrumentales, a lo largo de la película (Figura 1).

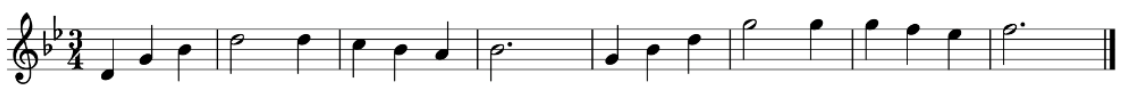

Figura 1. Motivo central de El increíble castillo vagabundo (transcripción nuestra).

Considerando las obras anteriores de Hisaishi para los films de Miyazaki, en esta película es la primera vez que Hisaishi utiliza el recurso mencionado (Bellano, 2010: 19; Koizumi, 2009: 67). Siguió experimentando con él en Ponyo en el acantilado (Gake no Ue no Ponyo), la siguiente película de Miyazaki en Studio Ghibli, y, de acuerdo con Bellano, su uso "tardío" se debería, en parte, a la metodología de la dupla (Bellano, 2010: 20). Koizumi, sin embargo, afirma que ello guarda relación con las convicciones del propio compositor, diciendo que es Hisaishi quien "critica las composiciones de leit motiv relacionadas a personajes porque para él son demasiado evidentes" (2009: 66).

El increíble castillo vagabundo se distingue de las otras películas también en su preproducción. A raíz de sus actividades profesionales internacionales, Hisaishi desarrolló otras ideas y procedimientos y compuso el álbum de imagen influido por sus nuevas experiencias (Bellano, 2010: 23). Al finalizar la producción, algunas de esas obras se incluyeron en el film, pero Miyazaki consideró que la propuesta para el tema principal no se correspondía con el tono del relato y le pidió a Hisaishi otra pieza (Koizumi, 2009: 67; Bellano, 2010: 24). Escogió una de las tres que Hisaishi le presentó, el vals llamado El tiovivo de la vida, cuyo motivo se convirtió en el hilo conductor de todas las transformaciones de Sophie, la protagonista, abarcando 18 (una se repite) de las 31 pistas del film (Tabla 3, p. 232).

En Kiki, entregas a domicilio también se presenta un personaje que se transforma, aunque ya no de manera física, como en El viaje de Chihiro (Haku, Yubaba) o El increíble castillo vagabundo (Sophie, Howl), sino de manera psicológica. El 
estado de ánimo de la protagonista tiene notables cambios y la banda sonora aporta mucho en este sentido. La música se limita a casos puntuales, el silencio es imperante a lo largo del film.

En su transcurso, se pueden escuchar dos temas pop vocales (uno en los créditos iniciales y otro en los finales). Sus letras no tienen que ver directamente con la historia y su estilo se aleja de las orquestaciones de Hisaishi. No obstante, aportan al contexto en el que se desarrolla la trama, otorgando tridimensionalidad al mundo construido. Para este efecto, se tomó una resolución muy bien lograda, cuando, al inicio, el tema de los créditos iniciales pasa de ser música de foso a ser música de pantalla (Chion, 2011: 82). Como resultado, se obtiene un ejemplo de música contextual, puesto que se alude a una época y una cultura particulares.

El viaje de Chihiro también se diferencia de las otras películas. Su duración es apenas mayor que la de El increíble castillo vagabundo y su CD incluye menos pistas que las de éste. Sin embargo, en El viaje de Chihiro intervienen más temas musicales a lo largo de todo el film que en El castillo o en Kiki. Este contraste se debe a que la mayoría de sus pistas se repiten una o dos veces más, mientras que, en las otras, sólo son tres pistas las que se repiten (Tablas 1, 2 y 3: celdas coloreadas de columna Soundtrack, pp. 230, 231 y 232).

Es importante recalcar que el hecho de que se repitan no tiene que ver con los motivos. Por una parte, en Kiki se dan dos motivos (uno en mayor medida que el otro) que no necesariamente se corresponden con las repeticiones de los "Soundtracks" (Figura 2). Sus temas han sido indicados por los colores verde y amarillo en la columna "Título" de la Tabla 1 (p. 230). Por otra parte, en El increíble castillo vagabundo se da un motivo central que se inserta periódicamente en el transcurso de la película, con variaciones mínimas o un poco más marcadas, y otro motivo, que alude directamente a un personaje. Los temas en los que es posible escucharlos se indican, respectivamente, con los colores verde claro, verde y lila en la Tabla 3 (p. 232).

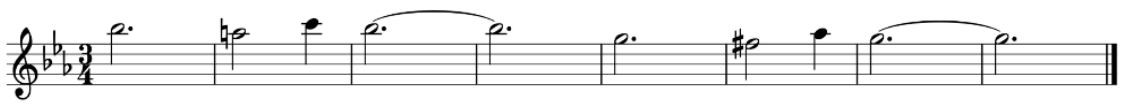

Figura 2. Motivo recurrente en Kiki, entregas a domicilio (transcripción nuestra)

\section{La magia del contraste}

Tomaremos los siguientes fragmentos de Kiki, entregas a domicilio, El viaje de Chihiro y El increíble castillo vagabundo en los que el planteamiento audiovisual es relevante, intentando distinguir qué elementos de la música son claves en la construcción de la atmósfera emotiva: 


\begin{tabular}{|c|c|c|c|}
\hline \multicolumn{1}{|c|}{ Película } & Minutaje de inicio & Minutaje de fin & Soundtrack \\
\hline \multirow{2}{*}{ Kiki, entregas a domicilio } & 0.13 .36 & 0.16 .24 & Una ciudad con vistas al mar \\
\hline El viaje de Chihiro & 1.24 .38 & 1.25 .38 & Un cuadro misterioso \\
\hline & 0.00 .10 & 0.03 .14 & Un dia de aquel verano \\
\hline El increíble castillo vagabundo & 1.50 .28 & 1.55 .15 & De nuevo \\
\hline & 0.00 .46 & 0.03 .00 & El tiovivo de la vida \\
\hline
\end{tabular}

Figura 3. Elementos musicales en tres películas.

La película basada en la novela japonesa homónima de Eiko Kadono, Kiki, entregas a domicilio, sigue las peripecias y vicisitudes de Kiki, una joven que, siguiendo una tradición para convertirse en bruja en pleno derecho, abandona la casa de sus padres a los trece años. La costumbre consiste, específicamente, en partir una noche de luna llena e instalarse durante un año en un pueblo ajeno al propio; en pocas palabras, en independizarse. Ya en los inicios de la película, Kiki monta en su escoba y parte con un único objetivo: establecerse en un pueblo donde pueda ver el mar. El sitio al que llega no es como el pueblo del que proviene, que es más cercano a lo rural. Tiene un aire europeo de las décadas finales del siglo XX y se caracteriza por su extensa costa y una alta torre del reloj (Figura 4). Cuando ve por primera vez el lugar, queda maravillada por completo.
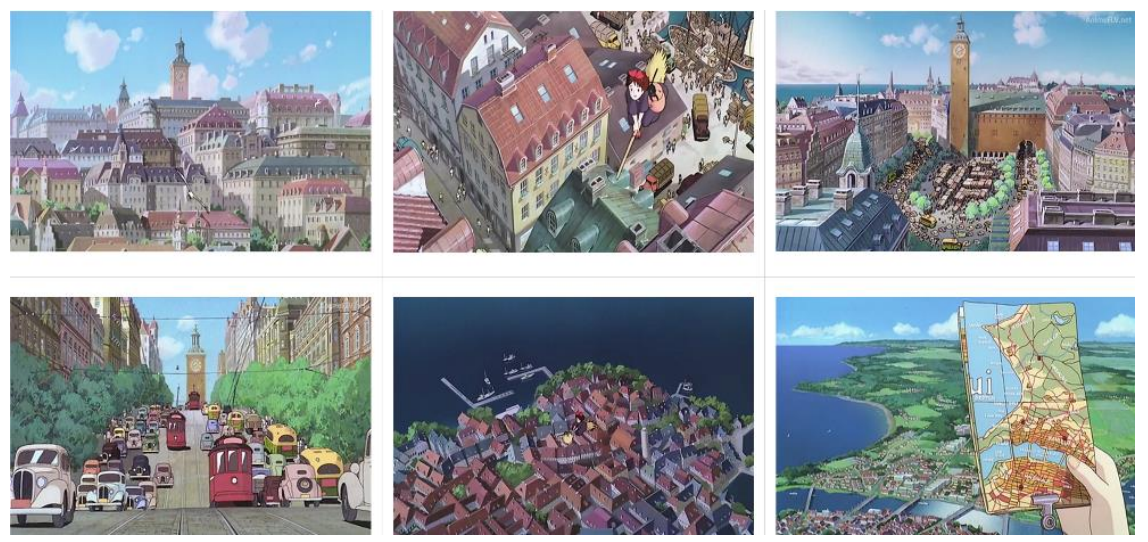

Figura 4. Representación del ambiente en Kiki, entregas a domicilio.

Tomaremos primero como ejemplo de relación música/imagen la secuencia en que Kiki ve por primera vez el pueblo. El desarrollo de la música, Una ciudad con vistas al mar, sin subrayar cada acción mostrada, crece a la par de las impresiones 
de la protagonista. Los cortes no corresponden a pulsos y el movimiento interno del plano tampoco guarda una relación estrecha con la música sino hasta el final.

La secuencia dura aproximadamente tres minutos desde que Kiki salta del tren y desciende al suelo. En su conjunto, logra transmitir características tanto de la protagonista como de Jiji (mascota que acompaña a Kiki) e, incluso, de la ciudad. La determinación, el optimismo, la suficiencia y el arrojo de Kiki se contraponen a la cautela y la prudencia de Jiji, con claridad. La ciudad, por otra parte, se puede apreciar como una metrópolis ajetreada y transitada, con variedad de tiendas, vehículos y personas.
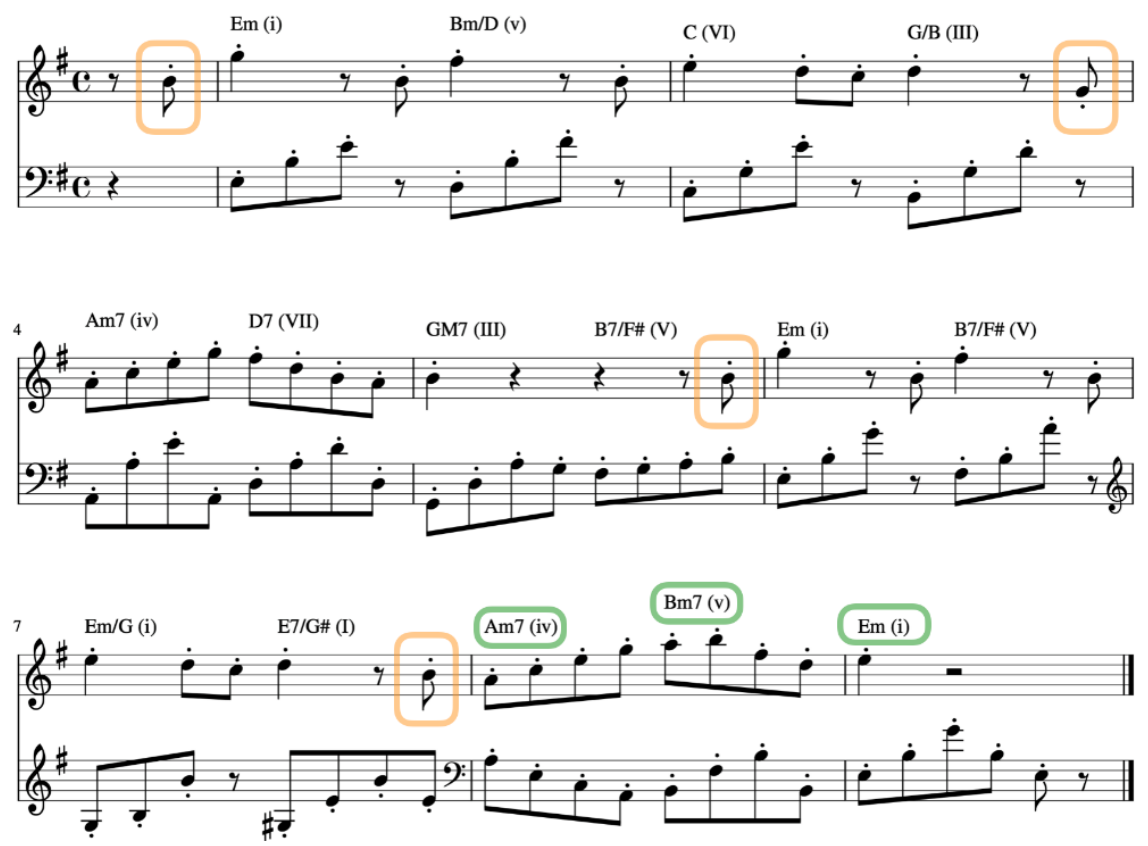

Figura 5. Fragmento de "Una ciudad con vistas al mar" (versión piano), de Kiki, entregas a domicilio (transcripción nuestra).

El tema de la pista" Una ciudad con vistas al mar", que acompaña esta secuencia, se repite en sólo dos ocasiones más durante la película. Las tres secuencias en las que aparece tienen en común el atrevimiento y la obstinación que caracterizan a Kiki en la parte inicial del film. Las figuras principales de la melodía, de predominancia descendente en el orden nombrado, son: corcheas, negras, blancas y cuartinas. Estas figuras son repartidas bajo una métrica de 4/4. La melodía se caracteriza por el uso de la técnica staccato y por el empleo de anacrusas. Las anacrusas provocan un ritmo de saltillo inverso en la línea superior y la sensación 
de galopas inversas en el bajo. La mayoría de las frases se abren en el tiempo débil de los compases y se cierran en uno fuerte. Hacia la mitad de la pista, se produce la variación más significativa que experimenta la melodía. De ésta destaca principalmente lo sincopado de la misma. Esta situación se debe a la acentuación dada por las anacrusas (Figura 5, anacrusas resaltadas en naranjo). En este tema musical en concreto, su uso genera ritmos de saltillo inverso, que son los que producen la sensación de un constante latido.

La tonalidad de Una ciudad con vistas al mar es Mi menor. Es decir, el acorde de Mi menor es la tónica del tema. En el sistema tonal, esto implica que deberían aparecer en su armonía los acordes de La menor (subdominante) y Si mayor (dominante) cerca de los finales de frases. En la armonía, predominan las funciones de tónica y subdominante, pero se evita el uso de la dominante, lo que sugiere que en el tema se emplea el sistema modal. El sistema modal consiste, a grandes rasgos, en diferentes sucesiones de sonidos que siguen estructuras únicas a partir de notas puntuales. En los últimos dos compases de la Figura 5 (acordes resaltados en verde), se puede ver gráficamente la cadencia modal básica, que se basa en utilizar el quinto grado menor antecediendo a la tónica $(v-i)$ y que carece de la característica conclusiva de la cadencia tonal. El que sea una música ágil, de ritmos de duración generalmente breve, parece maquillar el hecho de que la tonalidad predominante es menor, lo que se tiende a asociar a emociones negativas. Tampoco se transmite alegría o jocosidad, lo que demuestra el amplio espectro emotivo que abarca el lenguaje musical. Como la gama de los colores, la música no se rige por opuestos, sino por matices.

Sin ligarse a los cortes de la banda de imagen, "Una ciudad con vistas al mar" conjuga melodía y armonía con un resultado que termina por vincular las emociones e impresiones de Kiki al espectador. Los saltillos inversos originados por las anacrusas, junto a una instrumentación que ronda en las frecuencias medias graves $(500 \mathrm{~Hz})$, imitan perfectamente los latidos de un corazón ansioso. Se transmite una curiosidad implícita en el ascenso y descenso de notas de la segunda frase de la melodía (Figura 5, últimos dos compases), que finaliza con un paso de Fa\# a Re a Mi. Este hecho, que corresponde a los intervalos de tercera mayor y segunda mayor, respectivamente, otorgan una sensación de irresolución, de que algo falta.

Se puede distinguir una relación entre lo que se oye y lo que se muestra, un vínculo entre la música y la situación de la secuencia. La textura y la dinámica musicales son de determinada manera, mientras Kiki ingresa a la ciudad, y se mantienen constantes hasta que se produce un cambio de estado en la secuencia. Esta variación, a partir del minuto 15:01 en la película, también se corresponde con la introducción de un personaje, el señor de la torre del reloj, y con la conver- 
sación que Kiki entabla con éste. En la instrumentación, se produce una intervención importante del timbre de vientos y cuerdas, en especial del oboe y el fagot. La inclusión de ambos cobra un papel relevante mientras Kiki habla con el señor, momento en que, al igual que los personajes, estos instrumentos tienen una interacción de diálogo.

Cuando Kiki comienza su descenso por la ciudad (otra alteración de atmósfera en la secuencia), la transformación de la música es significativa: la métrica pasa de 4/4 a 3/4 e intervienen instrumentos que no se habían oído antes en el tema. La métrica de 4/4 marca un pulso constante, promoviendo una rítmica mantenida que puede reflejar rutina y, en otras ocasiones, misterio y suspenso; en este caso, genera expectación. La métrica de 3/4, por su parte, en esta secuencia favorece la alegría y la jovialidad, y su uso refuerza la pretensión de Kiki de descender con gracilidad. El cambio de métrica se produce en el clímax de la secuencia y, cuando Kiki evita chocar y provoca un caos en el tránsito, esta revolución de ritmos se distorsiona aún más. En la imagen, el desorden es evidente: los autos frenan abruptamente y en cualquier parte, la gente se mueve hacia un lado para evitar que la joven y su escoba descontrolada los choquen. El descenso de Kiki tras la confusión es paralelo al término de la música, que finaliza con suavidad tanto en su instrumentación (disminuye el grosor) como en su agógica (disminuye su velocidad).

La orquestación de "Una ciudad con vistas al mar" se podría denominar folclórica, porque alude a una cultura específica, a una ciudad de tradiciones, a una comunidad "a la antigua". La incorporación de la mandolina le otorga un carácter peculiar, ya que evoca a la música de países mediterráneos; le concede aires italianos (Koizumi, 2009: 66). Particularmente, en la segunda parte de la pista musical, cuando se produce el cambio de rítmica e instrumentación, sus características se pueden asociar a la música celta, que es también un estilo que se relaciona a tradiciones y raíces geográficas específicas. En la situación mostrada, el trabajo de música/imagen casi parece apuntar a una coreografía, a una danza.

Lo descrito nos permite conjeturar que algunas pistas de la banda sonora de Kiki, entregas a domicilio transmiten más que las imágenes con las que intervienen paralelamente. Esto se debe a que la música tiene la capacidad de activar recuerdos y generar asociaciones basadas en las experiencias del espectador. Esta capacidad funciona por sobre el vínculo que pueda promover la imagen o situación del relato.

Otro ejemplo de ello se presenta en la secuencia en que Kiki visita la cabaña de Úrsula. En esta secuencia, la joven bruja ingresa en la cabaña de la pintora y se queda observando el lienzo que ha pintado. Las figuras y los colores del cuadro llaman su atención y el ambiente se carga de la intensa emoción que le ocasiona. 
La atmósfera que se extiende en la secuencia no sería la misma sin la pista musical que se oye. "Un cuadro misterioso" transmite una sensación de relajo, tranquilidad, reflexión. Pese a que tiene timbres marcadamente electrónicos, la instrumentación en general alude a sonidos que se asocian al bosque, a la naturaleza. Se imitan al viento y al agua. La velocidad y la intensidad se mantienen constantes. El sustain provoca que la atmósfera se cargue de sonidos; en este caso, reflejando el embeleso en el que ha caído Kiki.

La música interviene cuando la pintura empieza a ocupar la totalidad del cuadro (en el sentido cinematográfico del concepto, es decir, dentro de los límites físicos que definen la imagen mostrada) y, cuando experimenta una variación, la imagen también cambia. Esto se corresponde con el grado de atención que le dedica la protagonista a la pintura (en lo visual, esto se aprecia con los cambios de plano). Si el tema musical "Un cuadro misterioso" es tan distinto del resto de las pistas que conforman la banda sonora, se debe a que su intervención en el relato coincide con un cambio de actitud en la protagonista. A lo largo de la historia, Kiki experimenta un desarrollo en su personalidad, que, como comprobamos, se demuestra tanto visual como musicalmente.

En El viaje de Chihiro, la secuencia inicial nos presenta a la protagonista y a sus padres. Adentro del auto, Chihiro no parece disfrutar del viaje, su actitud demuestra un completo rechazo y hastío. A través del diálogo, nos enteramos de que la familia se traslada al que será su nuevo hogar, haciéndose evidente que la niña se siente disgustada por ello. Además, se nos introduce sutilmente al mundo espiritual al que se dirigirá la historia. La secuencia dura poco más de tres minutos, desde que empieza hasta que termina, y remarca el protagonismo de Chihiro mediante planos subjetivos.

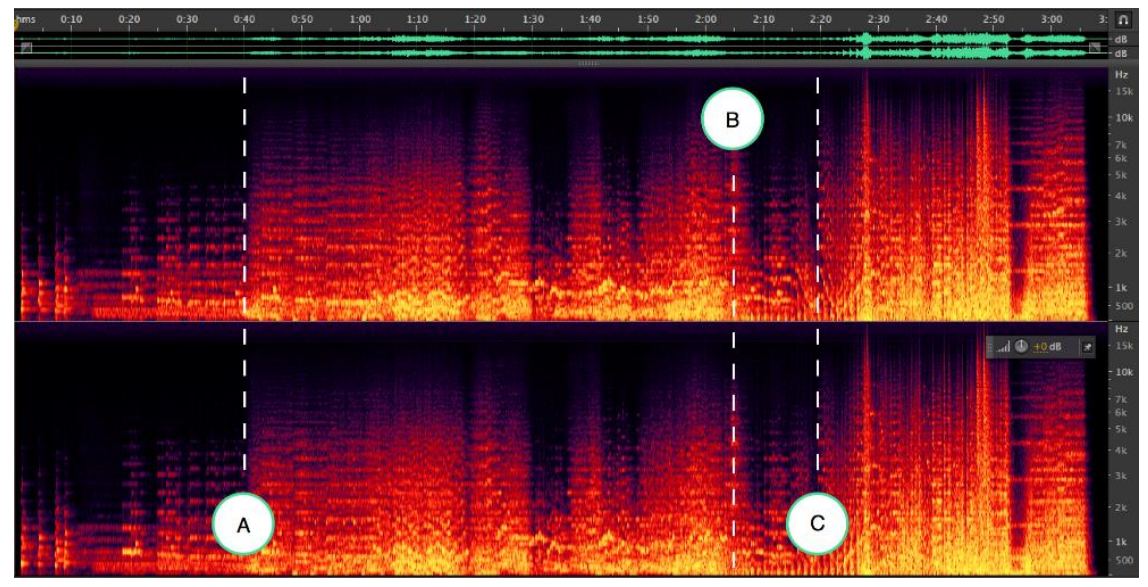

Figura 6. Espectrograma de "Un día de aquel verano", pista musical de El viaje de Chihiro. 
La música que se oye se titula "Un día de aquel verano". Su melodía se caracteriza por su sucesión de notas unísonas (notas en el mismo tono) y una constante repetición rítmica a nivel de frases, el uso de cuartas descendentes, que dan la impresión de irresolución, y finales de frase con intervalos de segunda mayor. Predominan las corcheas y, nuevamente, destacan las anacrusas, aunque en esta ocasión no se produce un ritmo sincopado. A los 2:12 minutos de la película, hay un cambio abrupto en la rítmica llevada hasta entonces y se introduce la técnica de staccatos. En esta sección se da un significativo cambio en la agógica y en la dinámica (Figura 6). Esta variación interviene precisamente cuando en la imagen hay una aceleración en el movimiento interno del film.

En la Figura 6 se pueden observar visualmente las alteraciones que experimenta la música. Respectivamente, a partir de los puntos señalados por las líneas A, B y $C$, se producen variaciones importantes en la textura (aumenta el grosor), la agógica (aumenta la velocidad) y la dinámica (aumenta la intensidad).

En cuanto a la armonía, podemos afirmar que está en tonalidad de La menor, aunque no inicia ni termina en el primer grado. Los acordes de apertura y cierre tampoco son idénticos entre sí. Definir la tonalidad, como en el caso de "Una ciudad con vistas al mar", se logra comprobando las funciones amónicas que estructuran el tema musical. Las frases generalmente terminan en semicadencias, es decir, descansan en un acorde distinto a la tónica (en este caso, acordes distintos a La menor). Las semicadencias se caracterizan por impedir el sentido de conclusión, dejando sin sentido de reposo al auditor. En la segunda parte de la música, la tonalidad pasa de La menor a $\mathrm{Si}^{\mathrm{b}}$ mayor. La presencia de $\mathrm{La}^{\mathrm{b}}$ y $\mathrm{Mi} \mathrm{C}^{\mathrm{b}}$ en determinado compás también sugiere un descenso a Fa menor. Debido a esto, se puede afirmar que la armonía tiene variaciones dentro de sí misma que van más allá de sus funciones, lo que, sumado al uso de séptimas, novenas y clusters al final, indica la complejidad del tema tras la aparente sencillez que supone la melodía.

En el tema musical, los finales de frase se caracterizan por la presencia de descensos y cierres inconclusos. Generar tensión no es el objetivo fundamental, pero el auditor queda con la impresión de que falta algo. No termina por producir tristeza tampoco, mas ni su rítmica ni su tonalidad se podrían clasificar como alegres. La emoción que se desprende oscila entre melancolía y nostalgia, se transmite una combinación de tristeza y alegría. Esto se produce principalmente por el descenso del intervalo de cuarta, que provoca indefinición y suspensión (una cuarta ascendente, por el contrario, ocasiona un efecto de conclusión).

En la segunda parte, pese a que también hay predominancia de armonías sin concluir, las emociones sugeridas cambian completamente. Esto se produce tanto por el aumento de la intensidad como por el incremento de la frecuencia 
media llevada hasta entonces. Se agregan además otros instrumentos, lo que aumenta el grosor de la textura musical, otorgando mayor consistencia tímbrica. Se sugiere inquietud, impaciencia, expectación, una predisposición a la aventura, a que algo va a suceder. La pista termina con la inclusión de clusters, técnica que aplicada a este caso juega un rol crucial porque genera irresolución y sugiere grandeza y misterio.

En la mayor parte de la secuencia, la pista musical y la banda de imágenes se relacionan estrechamente. De su vínculo se desprende un sentimiento de añoranza, de extrañar algo que ya no está o que se ha perdido. La música refuerza lo mostrado cuando, por segunda vez, la perspectiva del observador se sale del interior del auto, en un plano que indica la omnisciencia del narrador. Las alteraciones en la rítmica, la instrumentación, la agógica y la dinámica se presentan justamente al manifestarse los primeros indicios del mundo sobrenatural en el que se verán inmersos los personajes. Esto se remarca cuando la familia ingresa al bosque y el padre, quien conduce, acelera entre los árboles.

El inicio de la segunda parte de la pista musical se corresponde con la vuelta a la focalización sobre Chihiro. Este regreso hacia la protagonista se inicia con el mismo tipo de plano con el que parte el film: un plano subjetivo de la mirada de la niña (Figura 7). Este plano se contrapone con el inmediatamente siguiente, en el que vemos a Chihiro mirando por la ventana del auto. La relación entre música/imagen queda entonces establecida en el estado anímico de la protagonista: del desinterés (en lo visual) y la añoranza (en lo musical) a la curiosidad (en lo visual) y la expectación (en lo musical).

El uso de los metales destaca en esta segunda parte. La melodía asciende y desciende con staccatos, mientras el auto avanza por el camino pedregoso del bosque. Predominan las frecuencias medias (entre $250 \mathrm{~Hz}$ y $2000 \mathrm{~Hz}$ ) y, concretamente, las frecuencias de aquellos instrumentos, por sobre las de las cuerdas. La instrumentación utilizada en esta sección se aleja del timbre delicado del piano, pero el contraste generado se debe particularmente a la cantidad de instrumentos (cambio en la textura) y a la rítmica.

El enlace entre música/imagen se aprecia primordialmente en la variación en la agógica. Como en Kiki, la aceleración se liga a galopas y ritmos irregulares, y se acentúa el primer tiempo del compás para fortalecer el pulso. En este caso, ello otorga una sensación de apuro, de correr apresurado. La aceleración de la música actúa en paralelo a la aceleración del vehículo y es sólo interrumpida por la mirada de Chihiro. Los dos planos subjetivos que muestran la estatua de piedra de un ser sobrenatural, se corresponden con dos acordes, dos momentos de suspensión de corcheas y descanso en blancas. 
Un hecho curioso que surgió en este análisis fue notar que la utilización de los platillos crash interviene junto a las alertas de la madre. En la primera ocasión, la madre de Chihiro le advierte a la niña que se siente (Chihiro va inclinada entre ambos asientos delanteros). En la segunda, recrimina a su esposo por la velocidad a la que van, exclamando que los va a matar a todos. En el plano posterior, la imagen muestra que efectivamente hay un obstáculo y deben frenar de manera abrupta. Los clusters finales y el aumento de la intensidad realzan la construcción con la que se topan, mostrada además en un tilt up que refuerza la grandeza que se pretende darle. El edificio en sí no despierta mayor curiosidad, salvo por el lugar en el que está o la estatua de piedra que lo custodia, y, sin embargo, debido a la música, se ve mucho más imponente.
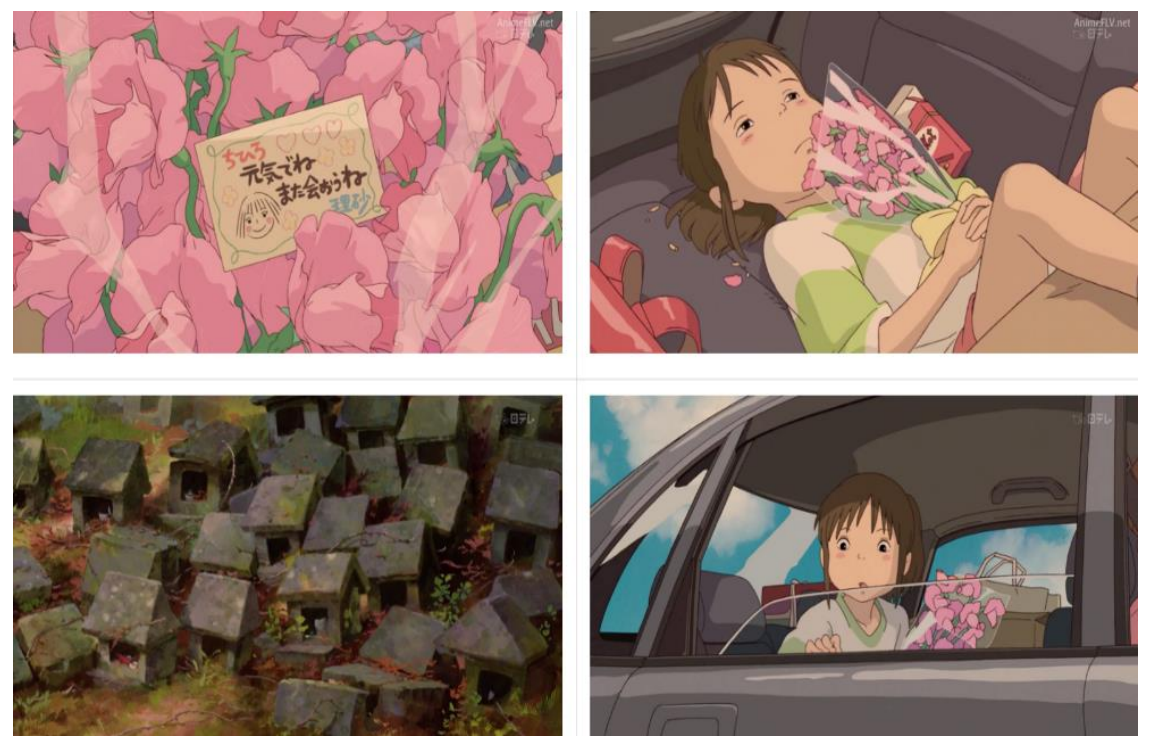

Figura 7. Plano subjetivo y contraplano siguiente en El viaje de Chihiro.

"Un día de aquel verano" se puede circunscribir en la orquestación tradicional por sus características estructurales y su instrumentación. A nivel de armonía, se aprecia una complejidad inesperada, incluso al evitar notas agregadas y adornos. Esto es a causa de los enlaces de las funciones armónicas, que siguen patrones muy distintos a los que acostumbramos oír. La sensación de irresolución que transmiten los finales de frase se debe, en parte, a nuestra percepción, pero también a nuestras experiencias musicales previas. Hisaishi emplea su arsenal musical a partir de su propia cultura oriental y, pese a que sus composiciones tengan reminiscencias europeas, en sus obras subyace su identidad a través de un estilo 
musical propio. El hecho de evitar la sensible (séptimo grado) se deriva del constante recurso a las escalas pentáfonas. En "Un día de aquel verano", la sensible de La menor, Sol\#, apenas aparece, lo que apunta nuevamente al sistema modal.

Como en El viaje de Chihiro, la música de El increíble castillo vagabundo también presenta la capacidad de otorgar o reforzar características de un personaje. A la protagonista se le atribuye un leit motiv, un conjunto de notas que la aluden y acompañan continuamente y que, sin embargo, a través de distintas variaciones, reflejan las transformaciones que ella experimenta.

En la secuencia inicial de esta película, se presenta el castillo de Howl y a la protagonista de la historia, Sophie. Suena la pista "El tiovivo de la vida" y se introduce fuertemente el motivo musical que intervendrá periódicamente a lo largo de todo el film. La pista musical no se repite en otras escenas/secuencias tal y como es, pero el constante resurgir del motivo vincula situaciones y personajes, de manera que la obra cinematográfica en su conjunto es un universo sólido y compacto. La melodía de "El tiovivo de la vida", en el film, comienza con acordes arpegiados de piano, mientras las cuerdas frotadas suenan en segundo término. Vientos y percusión se unen posteriormente, otorgando un aire oriental. El piano solo presenta lo que luego reconoceremos como motivo, consistente en el acorde de Sol menor arpegiado (en segunda inversión y luego en estado fundamental), algunas notas de paso y el quinto grado de Sol menor, Re menor. Bajo una métrica de 3/4, predomina el uso de negras y blancas. Los arpegios tienden hacia éstas. Cuando las blancas tienen una cualidad de reposo en el primer tiempo de un compás, la nota negra que le sigue funciona como anacrusa para el siguiente. Su velocidad es moderada y su naturaleza tímbrica, marcada. La mayor parte alterna la melodía del piano con los otros instrumentos. Hacia el final, se torna delicada al intervenir el arpa, la celesta y la flauta, sección que contrasta abruptamente con la siguiente, cuando se unen los demás instrumentos.

La tonalidad de esta pieza es Sol menor y se emplea el sistema tonal. La armonía comprende variaciones que caracterizan a las obras de Hisaishi. El uso de séptimas y novenas, dominantes secundarias y cambios de tonalidad, hacen de esta obra una pieza musicalmente compleja. Pese a que se pueden identificar algunos finales de frase con la función de dominante (irresolución), no genera expectativas. Al acogerse al sistema tonal, el séptimo grado sufre una alteración para adquirir su cualidad de sensible (asciende medio tono, pasando de Fa a Fa\#). El acorde sobre el quinto grado es afectado debido a ello y funciona como dominante de Sol menor. Disponer de la sensible implica mayores tensiones, mayor drama, lo que es un acierto musical respecto a la historia que se narra en la película. 
"El tiovivo de la vida" apunta al transcurrir de la vida, a los ciclos. Las notas ascienden y descienden, las frases se repiten de distintas maneras, el motivo se repite. Es una pista que transmite delicadeza y nostalgia en sus inicios y que, en su pausa final, sugiere una interrogación por resolver. El pulso ternario, de tres tiempos, permite un ritmo de vals que evoca vaivén, pues alude a un movimiento constante, a un continuo ir y venir. El uso de los acordes menores arpegiados en el piano le otorga un halo de tristeza a la obra en general, pero la incorporación de los otros instrumentos hace de esta emoción sólo una parte de la obra. El término de la pista, que no resuelve en la tónica, deja una línea melódica que no concluye: queda así expresada la necesidad de continuación.

Música e imagen se centran en la protagonista desde un principio, como en El viaje de Chihiro. La instrumentación y la textura cambian cuando irrumpe otro personaje en escena. Se añaden instrumentos de registros agudos, acompañados de uno de sonido grave en la percusión. Al momento siguiente, cuando se habla de Howl, se reinserta el motivo. La atención de la protagonista y de la narración se concentran en él. Hacia el final de la pieza musical, la indeterminación que se transmite refleja las dudas de Sophie, su incertidumbre, la situación inconclusa en la que está.

La aparición del motivo en más de la mitad de las pistas de la película plantea nuevos cuestionamientos en nuestra investigación. En base a los análisis de las bandas sonoras anteriores, se puede notar el peso que tiene la armonía. Tanto en Kiki, entregas a domicilio como en El viaje de Chihiro, las funciones armónicas juegan un papel importante en la construcción de la atmósfera emotiva. En El increíble castillo vagabundo la decisión de emplear la sensible para una historia dramática demuestra que también hay una atención sobre ella, pero la recurrencia del patrón armónico sugiere que otros elementos musicales también tienen un aporte clave en la atmósfera generada. Entre las pistas que conforman la banda sonora de El increíble castillo vagabundo, encontramos una cuyo análisis sugiere nuevas líneas de aproximación al asunto señalado.

Esta pista musical se puede escuchar en la secuencia en que se presenta la Bruja del Residual, cuando Sophie es hechizada en la tienda. En el soundtrack, se titula "La Bruja del Páramo". El tema musical se basa en una estructura de escala cromática, es decir, los tonos que intervienen están separados entre sí por intervalos de segunda menor (aunque también deja una sensación de escala de tonos enteros). La velocidad de las notas no rige su estructura por un ritmo metronómico, sino que crece y disminuye conforme se presentan los tonos de la escala. Se interpretan intervalos de tensión, mientras la velocidad y la intensidad varían de manera completamente independientes a la imagen (Figura 8). 
En la Figura 8, se puede observar visualmente el incremento de la intensidad y de las frecuencias agudas en la pista musical, que se corresponden con el aumento de la intranquilidad y tensión en el relato. Los puntos A y B señalan zonas en que se emplean frecuencias específicas a cargo de la ejecución del clarinete solista. El eje vertical del espectrograma arroja, bajo gradación de color, las frecuencias predominantes, por lo que es posible apreciar, a grandes rasgos, su fundamental (línea amarilla inferior) y sus armónicos (líneas superiores).

Esta música es el leitmotiv de la bruja. Un relato en sí mismo, sin vínculos con el lenguaje cinematográfico del montaje o la escala de planos, salvo al final. Su unión a la historia es meramente conceptual, hasta el hechizo, y esto se demuestra a través de las tres ocasiones en que interviene en la historia: las dos veces en que aparece la Bruja y cuando se alude a ella debido a un hechizo que envió en papel (Ver Tabla 3, celdas lilas columna Título, p. 232). El aumento de la intensidad y agógica en el tema musical, a partir de los 35 segundos, concuerda con la imagen de la Bruja atacando a Sophie; la pausa siguiente acompaña a su comentario de despedida y el cierre de la pista refuerza la amenaza velada al final de la secuencia.

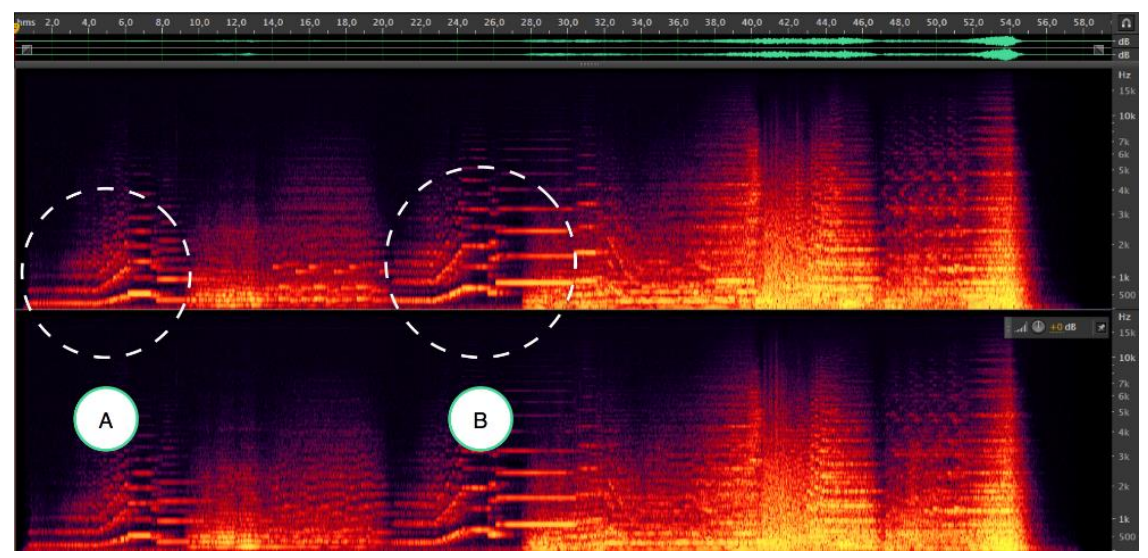

Fig. 8. Espectrograma de "La bruja del páramo", pista musical de El increíble castillo vagabundo.

Lo que transmite este tema se logra por las relaciones interválicas entre las notas y por el timbre de los instrumentos. La repetición sucesiva de los intervalos de segunda menor ascendente y tercera menor descendente provocan tensión, un sentimiento de amenaza, mientras que, al comienzo, predominan el misterio y la inquietud, emociones que no están ligadas al miedo de por sí. Por otra parte, la ejecución de las cuerdas frotadas también es un estímulo al desagrado y la turbación, pues, naturalmente, las frecuencias agudas no son gratas para nuestra per- 
cepción y la exposición permanente a ellas genera rechazo. Los dos aspectos mencionados ejemplifican que hay otros factores musicales que afectan contundentemente a la atmósfera emotiva en que se pretende envolver al espectador y que, en determinadas escenas, la armonía puede pasar a un rol secundario.

\section{Conclusiones}

El cine alcanza su máximo potencial al servirse de diferentes artes, porque cada una de ellas tiene un lenguaje propio que favorece la entrega del mensaje. La administración consciente y la labor conjunta de las áreas que intervienen siempre entregan un resultado superior. El trabajo coordinado de Hisaishi y Miyazaki es un ejemplo de que una obra audiovisual logra mayor impacto en los espectadores si la relación de música e imágenes es estrecha. Las competencias de director y compositor les permiten que, sin perder sus estilos propios, el vínculo audiovisual generado consiga un producto superior a lo que son los componentes por separado.

Studio Ghibli presenta en sus películas un estilo de animé tipo parábola; films que dejan una enseñanza, un aprendizaje (sea esto explícito o no). Al concluir las historias, las emociones experimentadas son positivas y, aun cuando no lo son directamente, buscan la reflexión del espectador. En Kiki y en El viaje de Chihiro, Hisaishi emplea el sistema modal para evitar la presencia de la sensible (VII grado), la que usualmente otorga un carácter dramático, precisamente porque estas películas no son dramáticas (en el sentido estricto del término). Del análisis de las bandas sonoras de las tres películas, podemos concluir que cada obra cinematográfica es un mundo distinto, aunque su género o temática sean los mismos. A grandes rasgos, los resultados de los espectrogramas de las bandas sonoras reflejan que la manipulación de sonidos/silencios tiene tendencia a corresponderse con la atmósfera general que se pretende dar a cada film (Figuras 9, 10 y 11, p. 229, y comparar). El análisis idéntico aplicado a cada película por separado demuestra que no existe una fórmula o molde para asegurar que se transmitan las mismas emociones al observar una película.

Estas tres películas demuestran que, en el cine, en general, existe una presencia influyente de la música. La banda sonora musical es capaz de afectar directamente en las historias, sin necesidad de supeditarse a las imágenes o al montaje. Puede no funcionar como una herramienta a favor de lo visual, ser partícipe en la entrega del mensaje e influir en las emociones del espectador sea cual sea la situación presentada. Se puede apreciar en todas las escenas revisadas que su actuación, paralela a la sucesión de fotogramas, no se limita a acompañar al movimiento interno o externo. De hecho, la música no tiene por qué vincularse con las imágenes de una secuencia de inicio a fin. En las tres escenas revisadas en detalle, por ejemplo, cuando los personajes conversan en pantalla, la música sigue su 
curso de manera independiente, tiene una vía propia. Esto es permitido por su cualidad de lenguaje, que la convierte en un recurso valioso cuando de doble discurso se trata.

Prácticamente, la música es una forma de expresar emociones. Los diversos elementos que la conforman afectan a la percepción en distintos grados. Componer música consiste en recurrir a unos o a otros y moldear la mezcla en base a lo que se quiere transmitir. En estas tres películas, la armonía es uno de los factores que cobra un papel crucial para la transmisión de emociones. Su presencia puede darse tanto en piezas extensas como en piezas breves y generar contrastes emotivos con sus variaciones. En base a nuestro análisis concluimos que la armonía sí es factor clave para generar la atmósfera emotiva de las escenas y de los films. Sin embargo, no es el único ni el predominante. Dependiendo de las situaciones a presentar narrativamente (es decir, considerando o no lo visual), las escenas/secuencias ameritan determinado tipo de música en la que es imprescindible una estructuración armónica precisa. El papel de la armonía es relevante, porque las relaciones sonoras afectan a la percepción tanto de manera biológica como cultural. Las funciones armónicas y el sistema musical en el que se desenvuelven pueden direccionar las emociones del espectador a un estado anímico específico. Las peculiares relaciones interválicas de las notas de cada uno de los grados, de los distintos tipos de acordes, les conceden propiedades sonoras particulares, y esto, aprovechado a conciencia por parte de compositores y directores, permite una ventaja sobre los espectadores. Se obtienen mejores resultados si previamente hay una planificación y fundamentación importantes.

Ocurre lo mismo al emplear otros elementos musicales que influyan en las emociones. Durante el trabajo de una obra audiovisual, se debe considerar que la decisión de recurrir a tal o cual factor afecta al producto, por lo que siempre se debe ir en pos de un objetivo. Decidir si la película llevará o no música, si el estilo debe o no mantenerse constante a lo largo del film, son resoluciones que se basan también en la historia que se quiere contar. ¿Qué se pretende al colocar tal sonido o música?

En el desarrollo del análisis, pudimos distinguir que otros factores de las bandas sonoras musicales tienen la capacidad de generar ambientes sonoros e inducir emociones. Comprobamos que sus intervenciones en las escenas/secuencias efectivamente consiguen construir una atmósfera emotiva y que dicha participación no es arbitraria. Dejando de lado intensidad y velocidad, que son cualidades inherentes a cualquier sonido, determinamos otros tres elementos musicales claves en la construcción de las atmósferas emotivas de las escenas: la distancia interválica entre notas, el ritmo y el timbre. Estimamos que este último es un elemento clave también, pero en menor medida. Los otros dos predominan sobre él. 
Se puede notar que llegamos precisamente a los otros dos factores que componen la música, ambos muy ligados entre sí junto a la armonía. La distancia interválica no es más que la melodía entendida bajo la concepción de Károlyi: la progresión gradual de sonidos, la progresión de saltos mayores y la combinación de ambos conjuntos (Károlyi, 2008: 77-78). Observamos que ritmo, armonía y melodía, de manera independiente, tienen efectos sobre nuestra percepción que se pueden vincular a emociones. Esto se debe a que están sometidas a las propiedades del sonido y, por ende, actúan en función del tiempo.

La melodía o distancia entre intervalos también tiene cualidades sonoras particulares. Una melodía en una escala cromática, una escala de tonos enteros o una escala pentáfona, ofrece diversas posibilidades de influir en el espectador, a causa de que la diferencia entre frecuencias, la distancia entre tonos, provoca emociones distintas. En la pista "La Bruja del Páramo", la inquietud y el misterio se deben, sobre todo, a los intervalos presentes.

El ritmo particularmente, guarda relación con la acentuación. Quizá, como en el caso de la melodía, podría remitirse a él en otras palabras: un factor musical importante es la acentuación de las figuras dentro de un compás. Las opciones son indiscutiblemente más reducidas respecto de lo que ocurre con el fenómeno melódico, ya que los ritmos se rigen por su duración y por el pulso, por la métrica. En el tema musical "Una ciudad con vistas al mar" podemos apreciar el crucial papel del saltillo inverso para transmitir la sensación de latidos, algo que se asocia al nerviosismo o a la ansiedad.

Agregamos el timbre como un factor importante musicalmente por su capacidad para construir ambientes sonoros y transportar a culturas específicas. Su poder de evocación, no obstante, se ve influido por la experiencia previa. El timbre puede sugerir emociones distintas según el rango frecuencial del instrumento. Al ser único para cada instrumento podemos distinguir a unos de otros (cuando no, sí distinguimos la familia a la que pertenece). La línea principal de "Un cuadro misterioso" en un instrumento de viento madera agudo, guía a un estado anímico distinto a que si se emplease un violín o un arpa.

Estos tres elementos, además de la armonía, son factores claves en la construcción de las atmósferas emotivas de las escenas de las tres películas revisadas. Servirse de ellos deriva del planteamiento previo que tiene lugar durante la preproducción y producción de los films, y ello confirma que, a nivel general, la música tiene una presencia influyente en el ámbito cinematográfico. El sonido de una obra audiovisual puede inducir a nuevas líneas de relato y entregar mensajes por sí solo. 


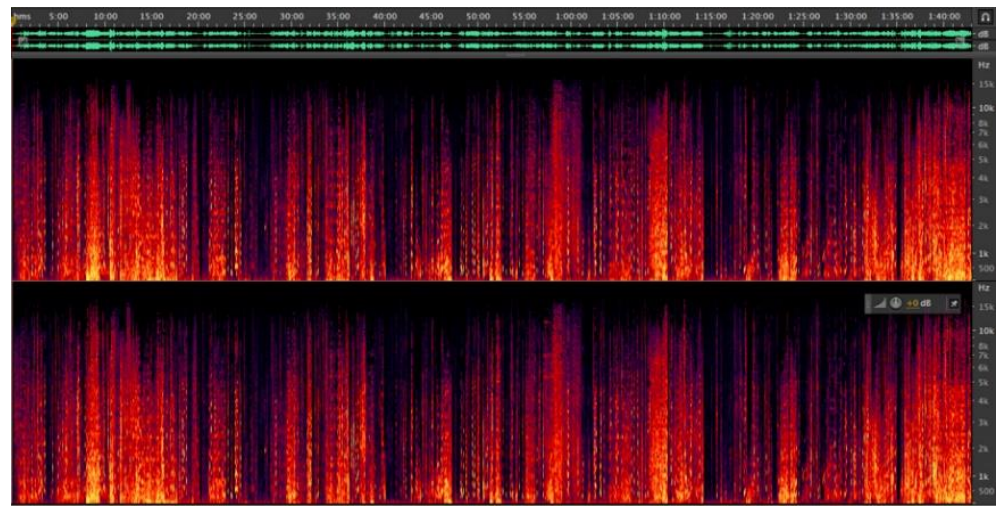

Figura 9. Espectrograma de "La bruja del páramo"

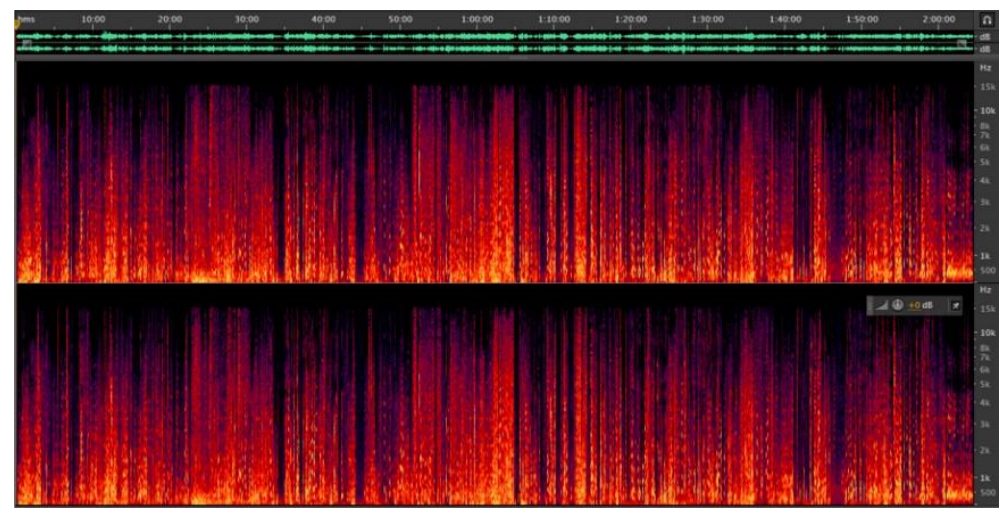

Figura 10. Espectrograma de "Una ciudad con vistas al mar"

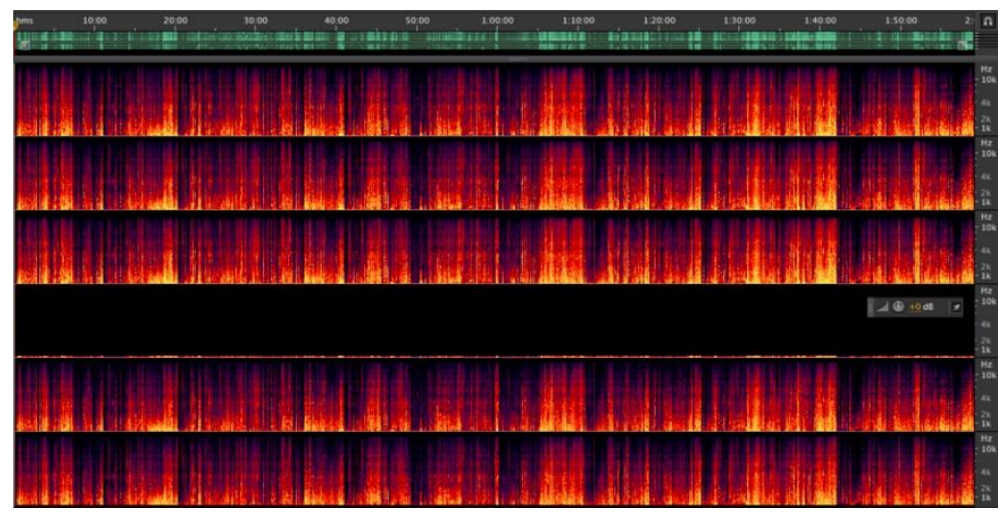

Figura 11. Espectrograma de "Un cuadro misterioso" 
Pamela Antillanca. Una música que construye. Elementos musicales claves para la generación...

\begin{tabular}{|c|c|c|c|c|c|c|}
\hline \multirow{2}{*}{\multicolumn{5}{|c|}{$\begin{array}{c}\text { Tabla } 1 \\
\text { Découpage musical de Kiki, entregas a domicilio }\end{array}$}} & \multirow{2}{*}{$\begin{array}{l}\text { Inicio película } \\
\text { Fin película }\end{array}$} & \multirow{2}{*}{0.00 .12} \\
\hline & & & & & & \\
\hline № & Inicio & Fin & Título & Duración & Soundtrack & OST \\
\hline 1 & 0.00 .39 & 0.02 .49 & La decisión de partir & 2.10 & En un día despejado & 2.16 \\
\hline 2 & 0.04 .45 & 0.07 .33 & Despedida & 2.48 & Saliendo de viaje & 2.54 \\
\hline 3 & 0.07 .57 & 0.09 .40 & Volando en la noche & 1.43 & Mensaje en rouge & - \\
\hline 4 & 0.13 .36 & 0.16 .24 & Un vistazo a la ciudad & 2.56 & Una ciudad con vistas al mar & 3.00 \\
\hline 5 & 0.20 .54 & 0.22 .58 & Entregando un chupete & 2.04 & Servicio de mensajería aérea & 2.09 \\
\hline 6 & 0.29 .28 & 0.30 .28 & Ayudando en la panadería & 1.00 & Ayudante en la panadería & 1.05 \\
\hline 7 & 0.31 .41 & 0.32 .11 & Muchachos en el auto & 0.30 & - & - \\
\hline 8 & 0.33 .40 & 0.35 .45 & La primera entrega & 2.05 & La primera entrega & 2.15 \\
\hline 9 & 0.38 .01 & 0.38 .52 & Juguete perdido & 0.51 & - & - \\
\hline 10 & 0.39 .38 & 0.40 .07 & El perro de Ketto & 0.29 & Jeff & 2.30 \\
\hline 11 & 0.42 .44 & 0.43 .00 & Dibujos animados de Ketto & 0.16 & Jiji, el sustituto & 2.47 \\
\hline 12 & 0.43 .09 & 0.43 .52 & El perro de Ketto & 0.43 & Jeff & 2.30 \\
\hline 13 & 0.44 .36 & 0.46 .51 & Jeff & 2.15 & Jeff & 2.30 \\
\hline 14 & 0.50 .41 & 0.51 .14 & Violines del televisor & 0.33 & - & - \\
\hline 15 & 0.51 .15 & 0.52 .28 & Entregas y trabajos & 1.13 & Una Kiki muy ocupada & 1.20 \\
\hline 16 & 0.55 .05 & 0.56 .12 & Horneando un pastel & 1.07 & Ayudante en la panadería & 1.05 \\
\hline 17 & 0.57 .04 & 0.58 .06 & Atrasada para la fiesta & 1.02 & Tarde para la fiesta & 1.08 \\
\hline 18 & 1.03 .47 & 1.06 .32 & Entrega a Kopori & 2.45 & El encargo de Osono & 3.02 \\
\hline 19 & 1.08 .47 & 1.10 .23 & La bicicleta de hélice & 1.36 & La bicicleta a hélice & 1.42 \\
\hline 20 & 1.10 .45 & 1.12 .47 & Conversando en la playa & 2.02 & - & - \\
\hline 21 & 1.19 .08 & 1.20 .13 & Sin magia & 1.05 & Kiki herida en sus sentimientos & 1.11 \\
\hline 22 & 1.22 .09 & 1.24 .13 & Hacia la cabaña de Úrsula & 2.04 & A la cabaña de Úrsula & 2.06 \\
\hline 23 & 1.24 .38 & 1.25 .38 & El cuadro de Úrsula & 1.00 & Un cuadro misterioso & 2.22 \\
\hline 24 & 1.26 .55 & 1.28 .58 & Descanso en la cabaña & 2.03 & Un cuadro misterioso & 2.22 \\
\hline 25 & 1.32 .39 & 1.33 .08 & El dirigible suelta amarras & 0.29 & El Espíritu Libertad fuera de control & 1.07 \\
\hline 26 & 1.38 .50 & 1.39 .48 & Rescate en el aire & 0.58 & Cita en el cepillo & 1.06 \\
\hline 27 & 1.39 .49 & 1.42 .57 & Mensaje & 3.08 & Envuelta en dulzura & - \\
\hline
\end{tabular}




\begin{tabular}{|c|c|c|c|c|c|c|}
\hline \multirow{2}{*}{\multicolumn{5}{|c|}{$\begin{array}{c}\text { Tabla } 2 \\
\text { Découpage musical de El viaje de Chihiro }\end{array}$}} & Inicio película & 0.00 .10 \\
\hline & & & & & Fin película & 2.00 .56 \\
\hline № & Inicio & Fin & Título & Duración & Soundtrack & OST \\
\hline 1 & 0.00 .10 & 0.03 .14 & Mudanza & 3.04 & Un día de aquel verano & 3.10 \\
\hline 2 & 0.04 .41 & 0.06 .34 & Un túnel misterioso & 1.55 & Camino de paso & 2.08 \\
\hline 3 & 0.07 .24 & 0.10 .34 & Un pueblo abandonado & 3.10 & Un restaurante vacío & 3.16 \\
\hline 4 & 0.11 .15 & 0.13 .07 & Fantasmas en el pueblo & 1.52 & El niño dragón & 2.12 \\
\hline 5 & 0.13 .13 & 0.14 .34 & El barco de los huéspedes & 1.21 & Los dioses & 3.00 \\
\hline 6 & 0.15 .08 & 0.17 .00 & Transparente & 1.52 & Comienza a anochecer & 2.00 \\
\hline 7 & 0.17 .01 & 0.18 .12 & Cruzando el puente & 1.11 & - & - \\
\hline 8 & 0.18 .13 & 0.18 .30 & Una intrusa en el pueblo & 0.17 & - & - \\
\hline 9 & 0.18 .30 & 0.19 .07 & Música de la casa de baños & 0.37 & - & - \\
\hline 10 & 0.19 .15 & 0.20 .20 & $\begin{array}{l}\text { Instrucciones para escon- } \\
\text { derse }\end{array}$ & 1.05 & Camino de paso & 2.08 \\
\hline 11 & 0.20 .56 & 0.22 .47 & Escaleras hacia Kamaji & 1.51 & - & - \\
\hline 12 & 0.25 .26 & 0.27 .55 & Los trabajadores de hollín & 2.29 & Bolas de hollin & 2.34 \\
\hline 13 & 0.30 .31 & 0.33 .28 & $\begin{array}{l}\text { Hacia las dependencias de } \\
\text { Yubaba }\end{array}$ & 2.57 & Los dioses & 3.00 \\
\hline 14 & 034.40 & 0.36 .15 & Conociendo a Yubaba & 1.35 & Yubaba & 3.30 \\
\hline 15 & 0.37 .42 & 0.38 .22 & La furia de Yubaba & 0.40 & La histeria de Yubaba & 1.38 \\
\hline 16 & 0.38 .32 & 0.40 .42 & Firmando un contrato & 2.10 & Yubaba & 3.30 \\
\hline 17 & 0.43 .05 & 0.44 .11 & Yubaba vigila & 1.06 & - & - \\
\hline 18 & 0.45 .12 & 0.47 .12 & Hacia la reunión con Haku & 2.00 & $\begin{array}{l}\text { La mañana en la casa de los ba- } \\
\text { ños }\end{array}$ & 2.02 \\
\hline 19 & 0.48 .28 & 0.51 .35 & $\begin{array}{l}\text { Haku y Chihiro en los jardi- } \\
\text { nes }\end{array}$ & 3.07 & El río de aquel día & 3.13 \\
\hline 20 & 0.52 .10 & 0.54 .32 & Trabajo en la casa de baños & 2.22 & El trabajo es duro & 2.27 \\
\hline 21 & 0.57 .11 & 0.57 .57 & $\begin{array}{c}\text { Sin cara en el cuarto de } \\
\text { baño }\end{array}$ & 0.46 & - & - \\
\hline 22 & 0.58 .11 & 1.02 .09 & El dios pestilente & 3.58 & El dios pestilente & 4.02 \\
\hline 23 & 1.03 .07 & 1.04 .30 & Limpiando al dios del Río & 1.23 & - & - \\
\hline 24 & 1.06 .12 & 1.06 .40 & $\begin{array}{c}\text { Celebración por el trabajo } \\
\text { de Chihiro }\end{array}$ & 0.28 & Los dioses & 3.00 \\
\hline 25 & 1.07 .09 & 1.08 .12 & Mirando al mar de lluvia & 1.03 & La sexta estación & 3.38 \\
\hline 26 & 1.08 .45 & 1.10 .07 & Sin cara reparte oro & 1.22 & - & - \\
\hline 27 & 1.12 .32 & 1.14 .12 & Haku, el dragón & 1.40 & El niño dragón & 2.12 \\
\hline 28 & 1.16 .29 & 1.16 .41 & $\begin{array}{c}\text { Sin cara se come a dos tra- } \\
\text { bajadores }\end{array}$ & 0.12 & - & - \\
\hline 29 & 1.16 .42 & 1.19 .12 & Hacia la oficina de Yubaba & 2.30 & El coraje de Sen & 2.45 \\
\hline 30 & 1.19 .56 & 1.20 .40 & En la habitación del bebé & 0.44 & Yubaba & 3.30 \\
\hline 31 & 1.21 .45 & 1.22 .59 & Huyendo del bebé & 1.14 & El agujero sin fondo & 1.19 \\
\hline 32 & 1.24 .48 & 1.25 .41 & Caída libre sobre Kamaji & 0.53 & El niño dragón & 2.12 \\
\hline 33 & 1.27 .17 & 1.27 .53 & Un bicho controlador & 0.36 & Bolas de hollin & 2.34 \\
\hline 34 & 1.29 .10 & 1.31 .19 & Ayudando a un dragón & 2.09 & El río de aquel día & 3.13 \\
\hline 35 & 1.32 .39 & 1.36 .20 & Sin rostro colapsa & 3.41 & Sin rostro & 3.47 \\
\hline 36 & 1.37 .37 & 1.41 .07 & A través el agua & 3.30 & La sexta estación & 3.38 \\
\hline 37 & 1.43 .48 & 1.45 .20 & ¡Bebé ha desaparecido! & 1.32 & La histeria de Yubaba & 1.38 \\
\hline 38 & 1.47 .20 & 1.48 .45 & Fondo del pantano & 1.25 & La casa en Fondo del Pantano & 1.30 \\
\hline 39 & 1.50 .28 & 1.55 .15 & Nuevos amigos & 4.47 & De nuevo & 4.54 \\
\hline 40 & 1.57 .43 & 2.00 .54 & Fin del contrato & 3.11 & El día de regreso & 3.21 \\
\hline 41 & 2.00 .58 & 2.04 .28 & Siempre conmigo & 3.30 & Siempre contigo & 3.35 \\
\hline
\end{tabular}


Pamela Antillanca. Una música que construye. Elementos musicales claves para la generación...

\begin{tabular}{|c|c|c|c|c|c|c|}
\hline \multirow{2}{*}{\multicolumn{5}{|c|}{$\begin{array}{c}\text { Tabla } 3 \\
\text { Découpage musical de El increíble castillo vagabundo }\end{array}$}} & \multirow{2}{*}{$\begin{array}{l}\text { Inicio película } \\
\text { Fin película }\end{array}$} & \multirow{2}{*}{0.00 .14} \\
\hline & & & & & & \\
\hline № & Inicio & Fin & Título & Duración & Soundtrack & OST \\
\hline 1 & 0.00 .46 & 0.03 .00 & El castillo y Sophie & 2.14 & El tiovivo de la vida & 2.34 \\
\hline 2 & 0.03 .51 & 0.04 .20 & Desfile de las tropas & 0.29 & La alegre caballería ligera & 0.51 \\
\hline 3 & 0.05 .00 & 0.07 .10 & Howl como escolta & 2.10 & Paseo por el cielo & 2.15 \\
\hline 4 & 0.09 .25 & 0.09 .43 & De vuelta hacia la tienda & 0.18 & Corazón acelerado & 0.21 \\
\hline 5 & 0.10 .05 & 0.10 .59 & La bruja del residual & 0.54 & La bruja del páramo & 0.59 \\
\hline 6 & 0.13 .38 & 0.16 .25 & Hacia las montañas & 2.53 & Sophie en el exilio & 4.20 \\
\hline 7 & 0.21 .18 & 0.22 .48 & Calcifer & 1.30 & La puerta mágica & 5.27 \\
\hline 8 & 0.22 .55 & 0.23 .07 & Marcha de la caballería & 0.12 & La alegre caballería ligera & 0.51 \\
\hline 9 & 0.23 .39 & 0.28 .50 & La puerta cambiante & 5.11 & La puerta mágica & 5.27 \\
\hline 10 & 0.31 .49 & 0.32 .28 & Un hechizo en papel & 0.39 & El hechizo permanente & 0.45 \\
\hline 11 & 0.33 .14 & 0.34 .31 & Limpiando el castillo & 1.17 & Limpieza general & 1.23 \\
\hline 12 & 0.36 .02 & 0.40 .09 & Hacia Star Lake & 4.07 & Hacia el lago de las estrellas & 4.13 \\
\hline 13 & 0.42 .38 & 0.43 .01 & Sophie duerme como niña & 0.23 & Un sentimiento callado & 0.28 \\
\hline 14 & 0.47 .42 & 0.49 .02 & Bajo la lluvia & 1.20 & Bajo la lluvia & 1.28 \\
\hline 15 & 0.51 .32 & 0.55 .24 & $\begin{array}{l}\text { Hacia Palacio a excusar a } \\
\text { Howl }\end{array}$ & 3.52 & Vanidad y amistad & 3.58 \\
\hline 16 & 1.02 .53 & 1.03 .48 & Defendiendo a Howl & 0.55 & Una niña de noventa años & 1.01 \\
\hline 17 & 1.05 .10 & 1.06 .40 & Suliman ataca & 1.30 & La magia de Sulimann & \multirow{2}{*}{5.23} \\
\hline 18 & 1.06 .51 & 1.09 .15 & Escape de Palacio & 2.22 & La vuelta al castillo & \\
\hline 19 & 1.11 .50 & 1.14.17 & La cueva de Howl & 2.27 & La cueva secreta & 2.34 \\
\hline 20 & 1.16 .13 & 1.18 .25 & Traslado & 2.08 & La mudanza & 3.06 \\
\hline 21 & 1.20 .26 & 1.23 .18 & Una pradera de flores & 2.52 & El jardín de flores & 2.58 \\
\hline 22 & 1.24 .25 & 1.25 .16 & Persecusión a Howl & 0.51 & ¡Vamos! & 0.57 \\
\hline 23 & 1.25 .44 & 1.26 .46 & Estás enamorada & 1.02 & Estás enamorada & 1.12 \\
\hline 24 & 1.29 .37 & 1.30 .55 & Una familia & 1.18 & Familia & 1.25 \\
\hline 25 & 1.31 .27 & 1.34 .17 & Hombres lodo & 2.50 & Amor en la guerra & 2.57 \\
\hline 26 & 1.35 .43 & 1.37.10 & El derrumbe del castillo & 1.27 & Huida & 1.33 \\
\hline 27 & 1.39 .14 & 1.41 .46 & Calcifer poderoso & 2.32 & El castillo de Sophie & 2.39 \\
\hline 28 & 1.44 .23 & 1.48 .12 & Howl y la estrella & 3.49 & El chico que se tragó una estrella & 7.30 \\
\hline 29 & 1.48 .22 & 1.51 .27 & Howl monstruo & 3.05 & El jardín de flores & 2.58 \\
\hline 30 & 1.52 .20 & 1.56 .32 & Amor verdadero & 4.12 & La promesa del mundo & \multirow{2}{*}{6.50} \\
\hline 31 & 1.56 .33 & 1.59 .05 & Vals final & 2.32 & El tiovivo de la vida & \\
\hline
\end{tabular}




\section{Referencias}

\section{Bibliografía}

Bellano, Marco (2010). The parts and the whole: Audiovisual strategies in the cinema of Hayao Miyazaki and Joe Hisaishi. Animation Journal (18). 4-54.

(2012). From Albums to Images. Studio Ghibli's Image Albums and their Impact on Audiovisual Strategies. TRANS-Revista Transcultural de Música / Transcultural Music Review (16). 2-16.

Károlyi, Ottó (2008). Introducción a la música. Madrid: Alianza.

Chion, Michel (2011). La audiovisión. Barcelona: Paidós.

Koizumi, Kyoko (2009). An animated partnership. En: Coyle, Rebecca, ed. Drawn to Sound: Animation Film Music and Sonicity. Londres: Equinox. 60-74.

Wynne Jones, Diana (2001). Howl's moving castle. Nueva York: Greenwillow Books.

\section{Filmografía}

Miyazaki, Hayao (director y productor) (1989). Kiki, entregas a domicilio. Japón: Studio Ghibli / NTV / Nibariki / Tokuma Shoten.

Suzuki, Toshio (productor); Miyazaki, Hayao (director) (2008). Ponyo en el acantilado. Japón: Studio Ghibli / Dentsu / Hakuhodo / NTV / Toho / Walt Disney Company / Taikei Office / Mitsubishi.

(2001). El viaje de Chihiro. Japón: Studio Ghibli / Tokuma Shoten / NTV / Dentsu / Buena Vista Home Entertainment / Tohokushinsha Film Corporation / Mitsubishi.

Suzuki, Toshio; Dempsey, Rick; Lott, Ned (productores); Miyazaki, Hayao (director). (2004). El increíble castillo vagabundo. Japón: Studio Ghibli / NTV / Dentsu / Buena Vista Home Entertainment / Tohokushinsha Film Corporation / Mitsubishi.

Takahata, I. (productor); Miyazaki, Hayao (director). (1984). Nausicaä del Valle del Viento. Japón: Hakuhodo / Nibariki / Tokuma Shoten / Topcraft. 